Al IBTIDA 3 (2): 269-279

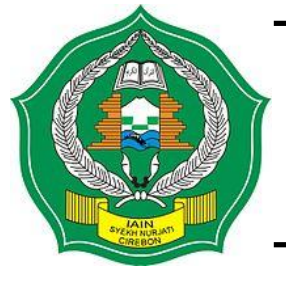

Al Ibtida

ISSN: 2442-5133

e-ISSN: 2525-7227

Journal homepage: www.syekhnurjati.ac.id/jurnal/index.php/ibtida Journal Email:pgmi@syekhnurjati.ac.id

\title{
MODEL PARTISIPATIF PENCEGAHAN DEMORALISASI PADA PESERTA DIDIK
}

\author{
Heryanto* \\ *Staf Pengajar Fakultas Ekonomi dan Bisnis Universitas Mulawarman \\ Email: heryfe@yahoo.co.id
}

\begin{abstract}
Abstrak
Tujuan penelitian ini adalah menganalisis dan mengevaluasi pencegahan demoralisasi pada peserta didik, sehingga diperoleh gambaran proses, pola dan faktor-faktor yang mempengaruhinya. Penelitian ini menggunakan pendekatan kualitatif. Metode penentuan sampel menggunakan teknik purposive sampling, dan snowball sampling, sedangkan ukuran sampel ditentukan berdasarkan kelengkapan informasi yang diperlukan. Data penelitian dikumpulkan melalui observasi, wawancara, kuesioner dan dokumentasi. Hasil penelitian memperlihatkan bahwa: (1) keluarga adalah lembaga pendidikan pertama yang mengajarkan moralitas, semenjak anak dalam kandungan; (2) setiap anggota keluarga menghargai secara demokratis, untuk untuk membangun percaya diri anak; (3) kehidupan keluarga berlandaskan nilai moral agama dan adat istiadat; (4) membangun komunikasi yang produktif dengan sekolah; (5) mengawasi dan mengevaluasi pergaulannya di lingkungan masyarakat; (6) orang tua selalu memberikan bantuan kepada anaknya jika ia menghadapi kesulitan
\end{abstract}

Kata kunci: agamis, demokrasi, demoralisasi, keluarga.

\begin{abstract}
The purpose of this study was to analyze and evaluate prevention demoralized students, in order to obtain an overview of the process, patterns and factors that influence it. This study used a qualitative approach. The sampling method using purposive sampling, and snowball sampling, while the sample size is determined based on the completeness of the information required. Data were collected through observation, interviews, questionnaires and documentation. The results showed that: (1) The family is the first educational institution that teaches morality, since the child in the womb; (2) every member of the family appreciated the democratic way, for children to build self-confidence; (3) the family life based on moral values of religion and customs; (4) building productive communication with the school; (5) monitor and evaluate the
\end{abstract}


interaction in society; (6) parents always provide assistance to the their child if he is facing difficulties.

Keywords: democratic, demoralization, families, religious.

\section{PENDAHULUAN}

Thomas Lickona, seorang pendidik dari Cortland University, yang dikutif Megawangi dan Sunarti (2003) mengungkapkan bahwa ada "tanda-tanda jaman" yang harus diwaspadai, karena kalau tanda-tanda ini sudah ada, maka sebuah bangsa akan menuju jurang kehancuran. Tanda-tanda tersebut adalah (1) meningkatnya kekerasan dikalangan remaja, (2) penggunaan bahasa dan kata-kata yang memburuk, (3) pengaruh peer-group yang kuat dalam tindak kekerasan, (4) meningkatnya perilaku yang merusak diri, seperti narkoba, sex bebas, dan alkohol, (5) semakin kaburnya pedoman moral baik dan buruk, (6) penurunan etos kerja, (7) semakin rendahnya rasa hormat kepada orang tua dan guru, (8) rendahnya rasa tanggung jawab individu dan warga negara, (9) ketidak jujuran yang telah begitu membudaya, (10) adanya rasa saling curiga dan kebencian di antara sesama.

Kasus bentrokan Satuan Polisi Pamong Praja dengan Polisi di Makasar tentu sangat mengejutkan dan memperihatinkan. Bentrokan yang terjadi tanggal 6 - 7 Agustus 2016 tersebut memberi indikasi tidak terawatnya moralitas para abdi negara. Padahal umat muslim Indonesia dan dunia baru saja melaksanan hari 'kemenangan' Idul Fitri 1437 Hijriah. Hari kemenangan itu tidak hanya dirayakan oleh umat muslim saja, tetapi juga oleh umat manusia lainnya. Bentrokan semacam itu tidak hanya terjadi di Makasar saja tetapi hampir merata di negeri ini. Begitu juga bukan yang pertama kali tetapi telah berulangkali terjadi. Tawuran pelajar, warga kampung, kota, lembaga atau organisasi masyarakat (ormas) telah menjadi pemandangan biasa. Ini merupakan bentuk penyimpangan dari perilaku masyarakat Indonesia. Bentuk penyimpangan lainnya antara lain pergaulan bebas, kejahatan, perusakan barang orang lain atau fasilitas umum dan lain sebagainya. Perilaku menyimpang ini telah menjadi masalah sosial yang tak pernah selesai. Seperti diungkapkan oleh Anekasari (2015) meningkatnya pergaulan bebas, maraknya angka kekerasan anakanak dan remaja, kejahatan terhadap teman, pencurian remaja, kebiasaan menyontek, penyalahgunaan obat-obatan, pornografi, dan perusakan milik orang lain sudah menjadi masalah sosial yang hingga saat ini belum dapat diatasi secara tuntas.

Beberapa akhli mensinyalir keadaan tersebut diakibatkan oleh rendahnya tingkat kecerdasan moral, sehingga tidak bisa membedakan mana yang baik dan tidak. Kelompok 
orang atau seseorang yang tidak memiliki kecerdasan moral akan selalu berhadapan dengan masalah sosial karena tidak memahami norma yang berlaku di masyarakat, baik norma agama maupun adat istiadat. Rendahnya tingkat pemahaman terhadap norma, tidak hanya menimpa golongan tertentu, tetapi juga para pelajar sebagai generasi penerus bangsa. Temuan Halimaking (2015) sebanyak 29,5-31,3 persen remaja NTT melakukan hubungan seks pranikah dan sekitar 60 persen di antaranya tanpa menggunakan alat pengaman. Yang lebih miris lagi, muncul fenomena bahwa siswa/i SMP dan SMA di NTT justru bisa membuat film seks atau porno untuk kemudian dilombakan di antara mereka, ada juga siswa yang merasa bangga jika berpacaran dengan tukang ojek atau sopir angkot.

Krisis yang melanda pelajar (juga elite politik) mengindikasikan bahwa pendidikan agama dan moral yang didapat di bangku sekolah (kuliah) tidak berdampak terhadap perubahan perilaku manusia Indonesia. Bahkan yang terlihat adalah begitu banyak manusia Indonesia yang tidak koheren antara ucapan dan tindakannya (Anekasari, 2015). Ada empat faktor yang menjadi penyebab demoralisasi pelajar antara lain media, kelalaian sekolah, rendahnya pengawasan orang tua, dan minimnya pelajaran moral di sekolah (Halimaking, 2015). Saat ini memang harus diakui bahwa media informasi, baik cetak, elektronik maupun maya (internet) dapat diakses secara bebas oleh siapa saja dan kapan saja. Rasa ingin tahu, akan mendorong anak mengakses informasi yang diinginkan tanpa memilih dan memilahnya. Informasi yang buruk bagi perkembangan jiwanya akan terus melekat menjadi proses internalisasi.

Kurikulum di sekolah nampaknya lebih mengutamakan pada aspek kognitif (pengetahuan) dibanding aspek afektif, sehingga sekolah berambisi untuk mencapai target jumlah lulusan. Demoralisasi di lingkungan pendidikan saat ini tengah berlangsung sejak dicanangkannya ujian yang dilaksanakan secara nasional. Beberapa sekolah akan berupaya untuk mencapai target kelulusan $100 \%$ dengan cara-cara yang kurang terpuji. Begitu juga dengan ujian masuk perguruan tinggi, ada pihak sekolah yang memberikan fasilitas mengubah nilai agar bisa diterima melalui jalur undangan. Di Samarinda pernah ada panitia penerimaan mahasiswa baru peruguruan tinggi memberi sanksi terhadap satu sekolah yang diduga memanipulasi nilai raport siswanya. Demoralisasi tidak hanya di tingkat SMA atau sederajat, tetapi secara berjenjang dari sekolah dasar sampai perguruan tinggi.

Kasus-kasus korupsi yang dilakukan berbagai kalangan termasuk di lingkungan lembaga pendidikan disebabkan oleh faktor. Wanaraja (2007) dalam Pusat Pendidikan dan Pelatihan Tenaga Kesehatan (2014) menyatakan bahwa salah satu penyebab paling utama 
dan sangat mendasar terjadinya korupsi di kalangan birokrat adalah menyangkut masalah keimanan, kejujuran, moral dan etika sang birokrat. Persoalan keimanan, kejujuran, moral dan etika bangsa telah menjadi persoalan nasional. Krisis moral yang menimpa bangsa kita adalah karena telah terabaikannya pendidikan moral (dalam pengertian pendidikan agama, budi pekerti, akhlaq, nilai moral) bagi generasi penerus (Nawawi, 2010). Dalam media informasi http://staff.uny.ac.id/), Marzuki menyatakan bahwa Presiden Republik Indonesia pada tahun 2010 mengajak seluruh rakyat Indonesia untuk bersama-sama membangun kembali karakter luhur bangsa yang sudah mulai pudar. Nilai-nilai karakter mulia yang dimiliki bangsa dan negara Indonesia sejak berabad abad dan sekarang sudah terkikis harus dibangun kembali terutama melalui pendidikan.

Berdasarkan pernyataan tersebut maka lembaga pendidikan menjadi bagian yang sangat penting dalam pembentukan moral bangsa Indonesia. Lembaga pendidikan harus melahirkan lulusan yang pintar secara intelektual dan terpuji secara moral (Anekasari, 2015). Intelektual berkaitan dengan pengetahuan dan keterampilan, sedangkan moral berkaitan dengan perilaku jiwa, sehingga terbangun kecerdasan moral dan intelektual. Jika kecerdasan moral terbangun maka akan terbangun juga kecerdasan intelektual. Nurrohman (2014) memberi kesimpulan pada penelitiannya bahwa terdapat hubungan yang signifikan antara kecerdasan moral dengan prestasi belajar siswa. Dengan demikian kecerdasan moral harus tumbuh menjadi karakter bangsa.

Berbagai strategi untuk membangun kecerdasan moral telah dilakukan oleh para pendidik di persekolahan, tetapi hasilnya belum optimal seperti yang diharapkan. Dari berbagai studi ternyata pembentukan karakter seseorang tidak hanya ditentukan oleh satu faktor saja tetapi multifaktor yang saling berkaitan. Di Indonesia terdapat tiga lingkungan pendidikan, yaitu pendidikan keluarga, sekolah, dan masyarakat. Ketiga lingkungan ini harus harus bersinergi secara integratif mendukung terbentuknya manusia Indonesia yang cerdas dan berkarakter mulia.

Kajian ini mencoba menganalisis dan mengevaluasi secara kualitatif proses pendidikan di lingkungan keluarga, sekolah dan masyarakat. Melalui kajian ini diharapkan diperoleh gambaran untuk membuat sebuah model alternatif penyelenggaraan pendidikan karakter di Indonesia. Model ini tentunya tidak dimaksudkan untuk menggantikan lembaga pendidikan yang telah ada tetapi memberikan suplemen perbaikan pada lingkungan pendidikan. Dengan demikian kontribusi dari masing-masing lingkungan akan nampak secara jelas. 


\section{METODE PENELITIAN}

Penelitian ini termasuk penelitian studi lapangan (field research) atau survey, yaitu penelitian yang bertujuan untuk memperoleh informasi utuh di lapangan atau situs penelitian. Penelitian dilakukan dengan menggunakan pendekatan kualitatif karena pengamatan terhadap proses interaksi sosial pada keluarga pada hakekatnya mengamati orang dalam lingkungan hidupnya, berinteraksi dengan mereka, dan berusaha memahami bahasa dan tafsiran mereka tentang dunia sekitarnya. Pengamatan terhadap keluarga harus bersifat utuh dari suatu sistem pada lingkungan tempat tinggalnya, karena realitas kehidupan keluarga sebagai suatu keutuhan yang tidak dapat dipahami maknanya jika dipisahkan atau terlepas dari konteksnya. Pendekatan kualitatif memungkinkan untuk mengungkap proses pembentukan perilaku anggota keluarga secara jelas, sehingga diperoleh maknanya. Penelitian ini dilaksanakan pada satu keluarga yang konsisten mengaplikasikan nilai moral agama pada kehidupan sehari-hari. Pertimbangan tempat tersebut sebagai situs penelitian karena terdapat subyek pengamatan yang memenuhi kretiria sebagai obyek pengamatan.

Penelitian ini dimulai bulan April 2012 dan selesai 28 Juli 2016. Lama penelitian tidak berdasarkan pada waktu yang ditentukan secara administratif tetapi berdasarkan pada pertimbangan lengkap atau tidaknya data yang diperlukan. Dengan demikian batas akhir waktu penelitian ditentukan di lapangan. Langkah-langkah penelitian terdiri atas prassurvey, orientasi pendahuluan, dan mengumpulkan data. Teknik pengumpulan data yang digunakan ialah pengamatan, wawancara, dan dokumentasi. Observasi yang dilakukan secara terlibat dengan kegiatan di lingkungan subyek penelitian. Agar dapat terlibat dengan responden, peneliti berbaur dan bergaul dengan subyek penelitian.

Pengambilan unit sampel menggunakan teknik purposive sampling, yaitu sampel bertujuan. Pertimbangan peneliti menggunakan teknik purposive sampling, karena keluarga yang diteliti dapat diamati secara terus menerus, termasuk tetangga dan keluarganya juga diteliti. Sampel pada pendekatan kualitatif relatif sedikit karena tidak ada ketentuan yang secara jelas yang mengatur ukuran sampel. Berkenaan dengan itu ukuran sampel ditetapkan satu keluarga. Penentuan key informan menggunakan teknik snowball sampling.

Instrumen yang digunakan untuk mengumpulkan data ialah peneliti sendiri, karena penelitian yang menggunakan pendekatan kualitatif, peneliti sendirilah yang menjadi instrumen utama yang terjun ke lapangan serta berusaha sendiri mengumpulkan informasi melalui observasi, wawancara dan penelaahan terhadap dokumen yang ada. Sebagaimana 
disarankan Spradley (1980) as participant observer, you will need to increase your instrospectiveness. In real sense, you will learn to use yourselt as a research instrument. Meskipun peneliti menggunakan panduan pengumpulan data, tidak berarti menutup kemungkinan terhadap adanya perubahan kegiatan. Data hasil penelitian yang telah terkumpul disajikan, direduksi ditarik kesimpulan dan diuji keabsahannya dengan teknik triangulasi data, yaitu melalui penggunaan metode, sumber, dan diskusi.

\section{HASIL DAN PEMBAHASAN}

\section{Hasil Penelitian}

Keluarga Bapak Marzuki tinggal di Desa Sumbersari Sebulu Kutai Kartanegara. Beliau memiliki tiga orang anak. Anak pertama perempuan, sedangkan kedua dan ketiga laki-laki. Beliau tinggal di desa tersebut sejak tahun 1980 mengikuti orang tuanya. Anak pertama Rani lahir tahun 1996 di rumah yang ditinggali sekarang, begitu juga anak kedua dan ketiga. Menurut cerita Pak Marzuki, semua anak selalu dilakukan doa selamatan, pada saat dalam kandungan maupun setelah lahir. Bapak Marzuki mengatakan:”Setiap anak pada usia empat dan tujuh bulan dalam kandungan diadakan selamatan, tujuannya untuk meminta perlindungan Gusti Allah agar kelak menjadi anak yang shaleh dan bertaqwa pada Allah".

Anak-anak Bapak Marzuki seluruhnya tergolong pintar mengaji (membaca) Al Qur'an, bahkan Rani sedang mengikuti kelompok pengajian hafidz Al-Qur'an di tempat ia kuliah. Membaca Al Qur'an dilakukan sehabis sembahyang Maghrib menjelang Isya di keluarga ini sifatnya wajib yang tidak bisa ditawar-tawar. Ibu Marzuki menjelaskan:"Saya yang pertama mengajari anak-anak mengaji dan sembahyang, awalnya ikut-ikutan aja tapi lama-lama jadi kebiasaan”. Mereka belajar mengaji tanpa huruf (hafalan) sejak usia satu setengah tahun, mulai dari bacaan doa yang sangat sederhana sampai yang panjang. Anakanak Bapak Marzuki memperoleh pelajaran mengaji tidak hanya dari orang tuanya saja, tetapi juga dari Surau dan sekolah. Metode yang dilakukan untuk mengajar mengaji awalnya disuruh dan dibujuk, jika menolak dipaksa. Berdasarkan pengalamannya, mengajarkan membaca Al Qur'an tidak sulit, karena adik-adiknya diajari oleh kakaknya atau temannya yang sudah pintar lebih dahulu.

Keadaan rumah Bapak Marzuki sangat sederhana tetapi cukup tertata rapi, ada tempat sembahyang dan wudlu. Jika menjelang sembahyang, orang tua Rani selalu menghentikan seluruh aktivitas kerja, mereka berkemas untuk melaksanakan sembahyang. Dengan cara seperti ini anak-anak menjadi ikut dan terbiasa, seperti dijelaskan Ibu Marzuki 
sebagai berikut:'Bapaknya anak-anak selalu berusaha sholat tepat waktu, jika sedang berada kumpul ya berjamaah. Setelah sholat ya kerja lagi atau istirahat”.

Ketika anaknya beranjak masuk sekolah, Bapak Marzuki selalu menghubungi guru atau kepala sekolah untuk konsultasi. Banyak yang dikonsultasikannya, mulai dari perilaku di sekolah sampai dengan prestasi belajarnya. Orang tua memang harus memonitor perilaku anaknya, baik langsung maupun melalui kepala sekolah, guru, atau teman-temannya. Menurut orang tua Rani, jangan bosan mengawasi anak karena kalau bosan dan jika terjadi sesuatu yang tidak diinginkan maka orang tua juga yang menanggung akibatnya. Atas dasar itu, keluarga Bapak Marzuki selalu ketat membimbing dan mengawasi anak-anaknya. Walaupun pekerjaan orang tua Rani petani, tetapi pergaulannya cukup luas sehingga ia mendapat masukan dari teman-teman pergaulannya. Rani masuk ke perguruan tinggi negeri di Samarinda atas saran kenalannya yang menjadi dosen.

Di lingkungan masyarakat, anak-anak Bapak Marzuki termasuk Rani, tergolong pribadi yang ramah, santun dan tahu etika dalam bergaul. Ketua RT-nya mengatakan:'Rani itu orangnya baik, tidak neko-neko seperti lainnya. Sangat sederhana tapi pintar bergaul sehingga banyak temannya yang suka dia”. Untuk membangun pergaulan yang sehat di masyarakat atau sekolah, Bapak Marzuki selalu memberi petunjuk agar menjaga nama baik. Maka dari itu nilai-nilai moral agama dan adat istiadat menjadi bagian penting dari kehidupan keluarganya.

\section{Pembahasan}

Tahap-tahap pendidikan keluarga dalam menanamkan moral pada anak memiliki banyak tahapan, mulai dari anak dalam kandungan sampai mandiri. Hal yang terpenting dalam pendidikan moral di lingkungan keluarga adalah komitmen. Komitmen orang tua dalam pengasuhan anak sangat diperlukan karena optimalisasi semua aspek tumbuh kembang individu pada tahun-tahun pertama kehidupannya sangat tergantung pada stimulasi yang diberikan orangtua (Megawangi dan Sunarti, 2003). Jadi orang tua memiliki peran yang sangat strategis dalam merawat dan membesarkan keturunan. Anak tidak tumbuh dengan sendirinya tetapi memerlukan bantuan orang lain.

Pola dan pendekatan yang dilakukan keluarga Bapak Marzuki sangat tepat, selain membekali nilai-nilai moral agama tetapi juga mengenalkan adat istiadat agar mudah bergaul di masyarakat. Keluarga merupakan lembaga pendidikan yang paling efektif untuk menanamkan nilai moral kejujuran, percaya diri dan keberanian. Jika terjadi kesalahan dalam memberikan pendidikan maka akan menimbulkan perilaku yang menyimpang. 
Menurut William Bennett yang dikutif Megawangi dan Sunarti (2003) The family is the original and most effective Department of Health, Education and Welfare. If it fails to teach honesty, courage, desire for excellence, and a host of basic skills, it is exceedingly difficult for any other agency to make up its failures. Dengan demikian pendidikan di lingkungan keluarga sangat efektif untuk membentuk anak berakhla mulia di banding lembaga lainnya. Peran seorang ibu menjadi penting karena dia merupakan sosok pendidik pertama yang dikenal anak. Jika pendidikan di lingkungan keluarga berjalan baik, maka pendidikan di sekolah dan masyarakat akan berjalan baik juga.

Kedudukan keluarga demikian penting maka sekolah dan masyarakat merupakan pelengkap bagi pendidikan anak. Keluarga mementuk kecerdasan moral, sekolah membentuk kecerdasan intelektual dan masyarakat membangun implementasi kecerdasan emosional. Oleh karena itu, orang tua, sekolah dan masyarakat harus bersinergi membentuk anak yang memiliki kepribadian akhlak mulia yang sarat dengan nilai moral agama dan adat istiadat. Untuk mencegah demoralisasi yang sedang melanda generasi bangsa Indonesia maka perlu revitalisasi fungsi keluarga sebagai lembaga pendidikan. Selain revitalisasi dan optimalisasi keluarga perlu juga dibangun "iklim" sekolah sebagai orang tua kedua. Dalam upaya membangun sekolah sebagai orang tua kedua maka posisi guru harus diberikan keluasan dan kewenangan menyelenggarakan pendidikan sesuai dengan Undang-undang. Guru dan penyelenggara pendidikan harus terbebas dari rasa takut dalam mendidik anak didiknya.

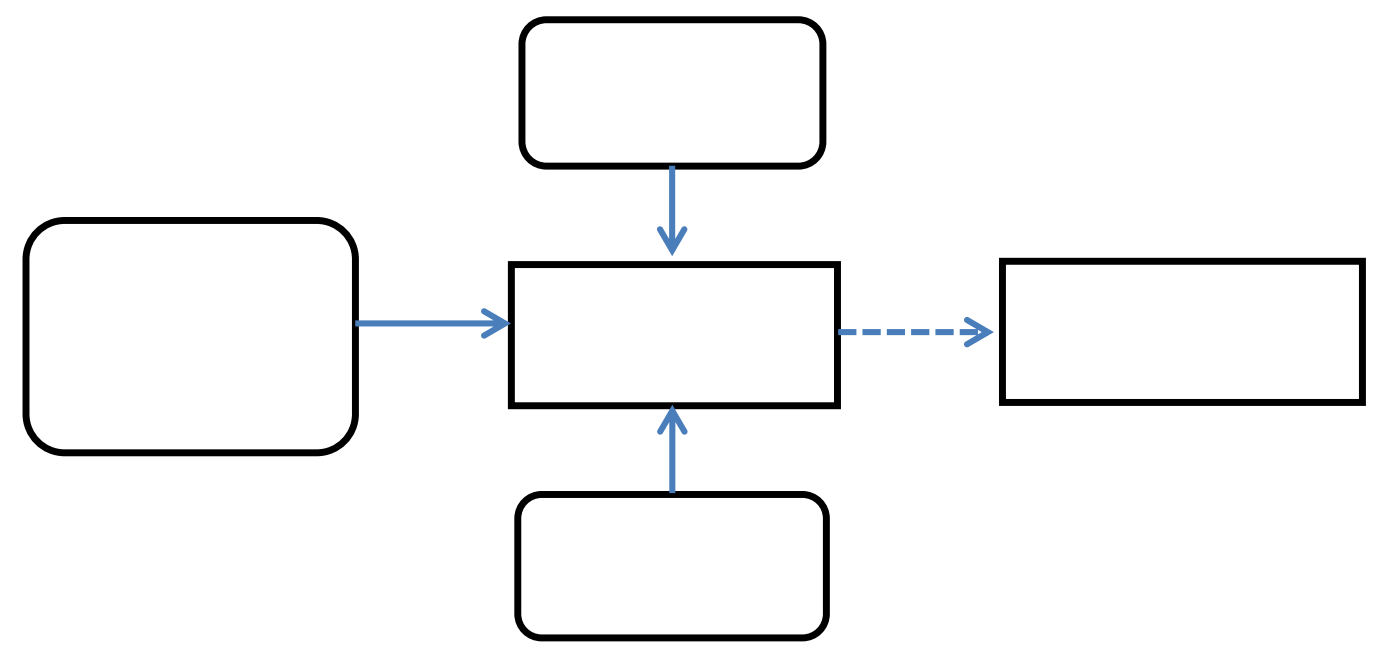

\section{Model Partisipatif Orang Tua, Sekolah dan Masyarakat Dalam Pencegahan Demoralisasi Peserta Didik}

Keterangan:

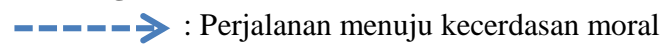

$\longrightarrow$ : Memberikan dukungan 
Pola penyenggaraan pendidikan berbasis kecerdasan moral harus berjalan secara terprogram dan berkesinambungan, antara keluarga, sekolah dan masyarakat. Berdasarkan hal tersebut maka pencegahan demoralisasi bangsa dapat dilakukan dengan pola atau model partisipatif. Dalam model partisipatif ini semua kelembagaan, baik formal maupun informal ikut terlibat membangun kecerdasan moral generasi muda.

Melalui model partisipatif seperti ini, para orang tua, sekolah dan masyarakat akan memahami proses pendidikan yang dijalani anak sebagai peserta didik. Partisipasi dari pemangku kepentingan ini dapat menekan kesalahpahaman antara orang tua, pihak sekolah dan masyarakat. Semua pihak tentu secara demokratis memberikan kontribusi sesuai dengan porsinya masing-masing.Tiga unsur-unsur ini harus memiliki tanggung jawab terhadap upaya mencerdaskan moral bangsa dan sekaligus mencegah terjadinya demoralisasi. Sekolah tidak bisa dipisahkan dari kehidupan keluarga peserta didik, dan begitu juga dengan masyarakat.

\section{SIMPULAN DAN SARAN}

\section{Simpulan}

Keberhasilan keluarga mencegah demoralisasi dimulai sejak dini yaitu pada lingkungan keluarga, karena lembaga tersebut merupakan penyelenggaran pendidikan yang pertama bagi generasi bangsa. Pendidikan dalam keluarga dimulai sejak anak dalam kandungan sampai tumbuh dewasa secara berkesinambungan. Pola pendidikan yang dianggap relevan dengan perkembangan jiwa anak ialah demokratis. Nilai-nilai moral agama harus ditanamkan secara dini yang diintegrasikan dengan nilai adat istiadat masyarakat.

Orang tua perlu bersinergi secara terbuka dengan sekolah dalam mendidik anak, karena orang tua dan sekolah memiliki keunggulan dan keterbatasan masing-masing. Atas dasar ini orang tua dan sekolah saling melengkapi. Orang tua harus selalu memonitor keadaan perkembangan anak di sekolah. Anak dipupuk untuk memandang sekolah sebagai orang tua kedua (guru-guru di sekolah sebagai penganti orang tuanya).

Orang tua senantiasa mengawasi dan memonitor pergaulan anak dengan temantemannya di masyarakat. Untuk mengenalkan adat istiadat yang berlaku di masyarakat maka orang tua harus memberikan penjelasan dan pemahaman kepada anak. Metoda yang paling efektif untuk menjelaskan dan memahami nilai-nilai adat isitiadat ialah memberikan contoh keteladanan dalam perilaku sehari-hari. 


\section{Saran}

Sekolah bukanlah lembaga pendidikan yang dapat menggantikan peran orang tua dalam keluarga, tetapi dapat dibangun menjadi lembaga penguatan karakter yang telah disemai oleh keluarga. Oleh karena itu untuk membangun karakter anak yang memiliki kecerdasan moral maka perlu dibangun kesadaran pada orang tua bahwa fungsi keluarga memiliki peran yang menentukan dalam membentuk pribadi anak yang berakhlak mulia.

Orang tua seyogyanya menjadi teladan bagi anak-anaknya karena proses peniruan perilaku oleh anak dimulai dari orang-orang terdekat dalam keluarga, terutama ayah dan ibu. Perlu ada senergi komunikasi yang baik antara sekolah, orang tua dan masyarakat. Moral generasi bangsa tidak hanya menjadi tanggung jawab satu pihak tapi senergi dari berbagai pihak.

\section{DAFTAR PUSTAKA}

Anekasari, Rahmi. (2015). Paradigma Pendidikan Islam Multidimensional: Konsep dan Implikasinya dalam PAI di Sekolah/Madrasah. Jurnal Hikmatuna, Vol. No. 1: 99130.http://e-journal.stainpekalongan.ac.id/index.php/hikmatuna/article/view/474/763 [diakses 02-08-2016].

Halimaking, Igo. (2015). Demoralisasi Pelajar, Refleksi Kelemahan Pendidikan. http://floringgo.blogspot.co.id/2015/04/ [diakses 06-08-2016].

Harsojo, A. (2013). Membangun Karakter Berkearifan Lokal Dalam Bingkai Pendidikan Persekolahan. Jurnal Pelopor Pendidikan Volume 4, Nomor 1: 19-28, Januari 2013. www.stkippgrismp.ac.id/backsite-content/uploads/2013/08/Ali-Harsojo.pdf [diakses 04-08-2016]

Jannah, Husnatul. (2012). Bentuk Pola Asuh Orang Tua Dalam Menanamkan Perilaku Moral Pada Anak Usia di Kecamatan Ampek Angrek. Jurnal Pesona PAUD, Vol I, No 1: 1-10. http://ejournal.unp.ac.id/ [diakses 04-08-2016].

Judrah, M. (2016). Pembinaan Orang Tua Dalam Pembentukan Akhlak Anak. Jurnal AlQalam Volume 8 Nomor 1: 65-76, Tahun 2016. www.iaim-sinjai.ac.id [diakses 20-082016]

Karendehi, CED dkk. (2016). Hubungan Pola Asuh Orang Dengan Kecerdasan Moral Pada Anak Usia 12-15 Tahun di SMP Negeri 1 Tabukan Selatan Kepulauan Sangihe. Ejournal Keperawatan (e-Kp) Volume 4 Nomor 1:1-6, Februari 2016. http://ejournal.unsrat.ac.id/index.php/jkp/article/view/10795 [diakses 07-08-2016]

Kurnia, Ingridwati. Perkembangan Intelek, Bahasa, Moral dan Kepribadian Peserta didik. http://educloud.fkip.unila.ac.id/ [diakses 04-08-2016]

Mahlawi, PN dan Rachma, N. (2012). Permasalahan Remaja yang Tinggal di Area Lokalisasi Gambilangu Semarang. http://jurnal.unimus.ac.id/index.php/ psn12012010/article/viewFile/1282/1335 [diakses 20-07-2016] 
Megawangi, R dan Sunarti, E. (2003). Peran Keluarga Dalam Membangun Bangsa Berkualitas: Penghargaan Kembali Terhadap Kiprah Wanita Dalam Mengasuh Anak. Makalah Seminar Nasional Peran dan Fungsi Wanita Dalam Perspektif Umat. Kesyukuran Setengah Abad Pondok Pesantren Al-Amien, Prenduan, Sumenep, Madura 24 Januari 2003. http://euissunarti.staff.ipb.ac.id (diakses 08-08-2016]

Na'imah, Tri. (2014) Internalisasi Karakter Sosial Melalui Budaya Sekolah. Prosiding Seminar Hasil Penelitian. LPPM UMP 2014 ISBN 978-602-14930-2-1 Purwokerto, 6 September 2014: 206-212. https://publikasiilmiah.ums.ac.id/handle/11617/6449 ?show=full [diakses 20-08-2016]

Nawawi, Ahmad. (2010). Pentingnya Pendidikan Moral Bagi Generasi Penerus. Skripsi. Bandung. Jurusan PLB FKIP Universitas Pendidikan Bandung.

Nurrohman, M.F. (2014). Hubungan Antara Kecerdasan Moral Dengan Hasil Belajar Pada Siswa Kelas VA SD Negeri 81 Bengkulu. Skripsi. Bengkulu. Program Studi PGSD FKIP Universitas Bengkulu.

Pertiwi, E. dkk (2016). Pola Asuh Orang Tua Dengan Perkembangan Sosial (Percaya diri) Remaja di SMA Negeri 7 Manado. E-journal Keperawatan (e-Kp) Volume 4 Nomor 2: 1-7, Juli 2016. http://ejournal.unsrat.ac.id/index.php/jkp/article/view/12911. [diakses 07-08-2016]

Pranoto, Y.K.S. (2011). Kecerdasan Moral Anak Usia Prasekolah. http://journal.unnes.ac.id [diakses 01-08-2016]

Pusat Pendidikan dan Pelatihan Tenaga Kesehatan. (2014). Buku Ajar Pendidikan dan Budaya Antikorupsi. Jakarta: Pusat Pendidikan dan Pelatihan Tenaga Kesehatan.

Qumi, Laila. (2011). Stimulasi Kecerdasan Spiritual Pada Periode Pendidikan Pranatal dalam Perspektif Islam. Skripsi. Salatiga: Jurusan Tarbiyah. Program Studi Pendidikan Agama Islam, Sekolah Tinggi Agama Islam Negeri Salatiga.

Rochendi, Moch. (2010). Pengaruh Keluarga Brokenhome terhadap Prestasi Belajar dan Akhlak Siswa (Studi Kasus di SMK Negeri 1 Kadipaten). Thesis. Cirebon: Program Pascasarjana Program Studi Pendidikan Islam IAIN Syekh Nurjati. https://www.scribd.com/documen [diakses 07-08-2016]

Sari, D.P. (2013). Perbedaan Kecerdasan Moral antara Remaja yang Mengikuti dan Tidak Mengikuti Program "Gerakan Kembali ke Surau”. http:// ejournal.unp.ac.id /students/index.php/psi/article/view/596 [diakses 04-08-2016].

Solina, Emmy. (2013). Keluarga Broken Home di Tanjung Pinang. http://riset. umrah.ac.id/wp-content/uploads/2013/Emmy-Solina-BrokenHome-pdf [diakses 2006-2016]

Susanto, E. (2006). Pendidikan Agama Berbasis Moderatisme (Melacak Kontribusi Nahdatul Ulama).Tadrîs. Volume 1. Nomor 2: 168-184.Tahun 2006. http://ejournal. stainpamekasan. ac.id/index.php/tadris/article/view/190 [diakses 20-06-2016]

Triana, Lely. (2011). Pola Penerapan Pendidikan Karakter Siswa di SMA Negeri 3 Pati. Skripsi. Semarang: Jurusan Hukum dan Kewargaan Negara, Fakultas Ilmu Sosial Universitas Negeri.

Zubaedi, M. 92015). Pendidikan Karakter Melalui Pola Pembelajaran Integralistik. www.ispi.or.id/2015/04/11/pendidikan-karakter-melalui-pola-pembelajaranintegralistik/ [diakses 02-08-2016] 